\begin{tabular}{|c|c|c|}
\hline $\begin{array}{l}\text { 2. To: (Receiving Organization) } \\
\text { Fuels And Materials Examination Facility }\end{array}$ & $\begin{array}{l}\text { 3. From: (Originating Organization) } \\
\text { fuels And Materials Exemination Facility }\end{array}$ & $\begin{array}{l}\text { 4. Reloted EDT No.: } \\
\text { NA }\end{array}$ \\
\hline $\begin{array}{l}\text { 5. Proj./Prog./Dept./Div.: } \\
\text { FMEF/Fuel Fabrication Operations }\end{array}$ & $\begin{array}{l}\text { 6. Desion Authority/ Design Agent/Cog. } \\
\text { Engr.: SK Fong }\end{array}$ & 7. Purchase Order No.: \\
\hline \multirow{2}{*}{\multicolumn{2}{|c|}{$\begin{array}{l}\text { 8. Originator Renarks: } \\
\text { Supporting Document HNF-3584 provides a basis for understanding of the confidence } \\
\text { levels used in the FMEF Electrical Single Line Diagram and Panel Schedule } \\
\text { Verification Process. }\end{array}$}} & $\begin{array}{l}\text { 9. Equip./Component No.: } \\
\text { NA }\end{array}$ \\
\hline & & $\begin{array}{l}\text { 10. System/Blo. /Facility: } \\
\text { 61A,B,C,D,E/427,4862/FMEF }\end{array}$ \\
\hline \multirow[t]{3}{*}{ 11. Receiver Remarks: } & \multirow[t]{3}{*}{ Iasel ine Document? [x] Yes [] No } & $\begin{array}{l}\text { 12. Major Assm. Dng. No.: } \\
\text { Wh }\end{array}$ \\
\hline & & $\begin{array}{l}\text { 13. Permit/Permit Application No.: } \\
\text { WA }\end{array}$ \\
\hline & & $\begin{array}{l}\text { 14. Required Response Date: } \\
11-11-98\end{array}$ \\
\hline
\end{tabular}

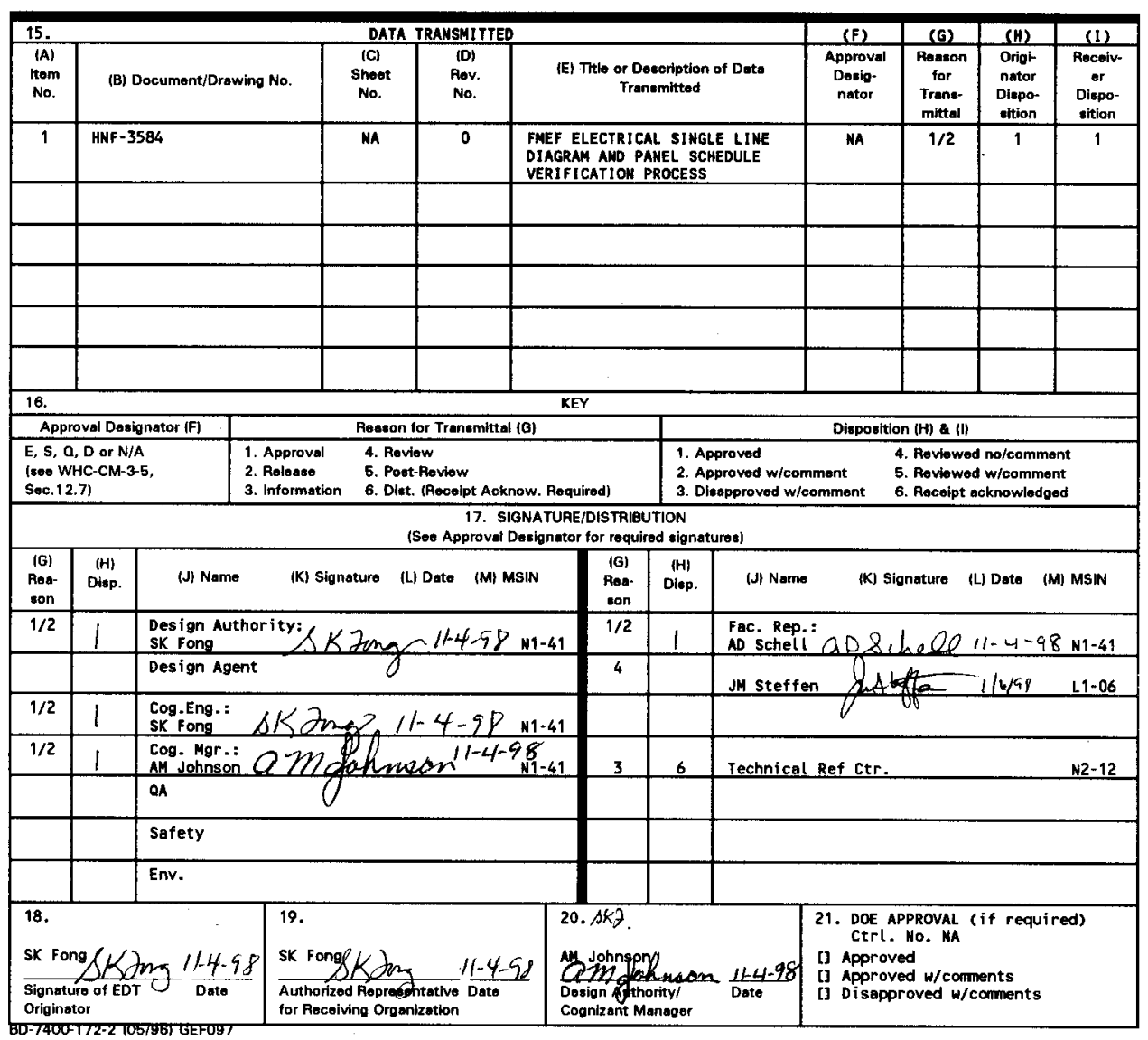




\section{FMEF ELECTRICAL SINGLE LINE DIAGRAM AND PANEL SCHEDULE VERIFICATION PROCESS}

S. K. Fong

BWHC, Richland, WA 99352

U.S. Department of Energy Contract DE-AC06-96RL13200

$\begin{array}{lll}\text { EDT/ECN: } & \text { EDT } 617713 & \text { UC: } 900 \\ \text { Org Code: } & 19100 & \text { Charge Code: } 101587 \text { AJ60 } \\ \text { B\&R Code: } & \text { YNO1 } & \text { Total Pages: } 12\end{array}$

Key Words: drawing verification program, electrical, single line diagram, panel schedules, FMEF, electrical drawing field verification, confidence leve1

Abstract: Since the FMEF did not have a mission, a formal drawing verification program was not developed, however, a verification process on essential electrical single line drawings and panel schedules was * established to benefit the operations lock and tag program and to enhance the electrical safety culture of the facility. The purpose of this document is to provide a basis by which future landlords and cognizant personnel can understand the degree of verification performed on the electrical single lines and panel schedules. It is the intent that this document be revised or replaced by a more formal requirements document if a mission is identified for the FMEF.

TRADEMARK DISCLAIMER. Reference herein to any specific comercial product, process, or service by trade nane, trademark, manufacturer, or otherwise, does not necessarily constitute or imply its endorsement, recommendation, or favoring by the United States Government or any agency thereof or its contractors or subcontractors.

Printed in the United States of America. To obtain copies of this document, contact: Document Control Services, P.0. Box 950, Mailstop H6-08, Richland WA 99352, Phone (509) 372-2420; Fax (509) 376-4989.
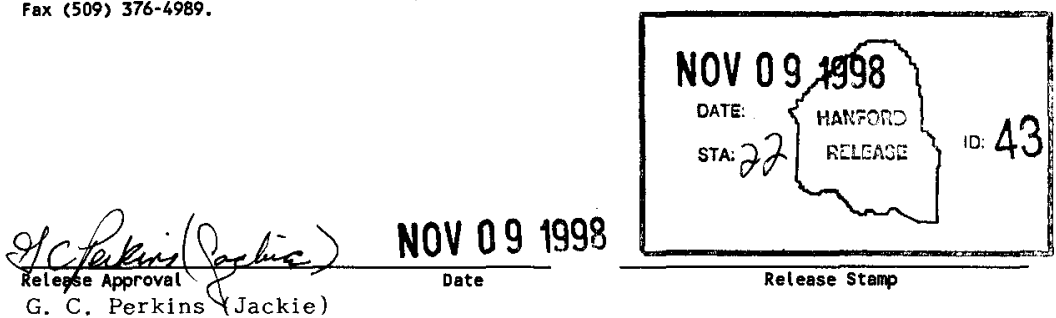

\section{Approved for Public Release}




\section{RELEASE AUTHORIZATION}

Document

Number:
HNF-3584, Rev. 0
Document

Title:
FMEF ELECTRICAL SINGLE LINE DIAGRAM AND PANEL SCHEDULE VERIFICATION PROCESS

This document, reviewed in accordance with DOE

Order 1430.1D, "Scientific and Technical

Information Management," and DOE G 1430.1D-1,

"Guide to the Management of Scientific and

Technical Information," does not contain classified

or sensitive unclassified information and is:

\section{APPROVED FOR PUBLIC RELEASE}

Lockheed Martin Services, Inc.
Document Control/Information Clearance

Reviewed for Apptied Technology, Business Sensitive, Classified, Copyr ghted, Export Controlled, Poteht, Personal/Private, Proprletary, Protected CRADA, Trademark, Unelassified Control led Nucl bar Informat lon.

LEGAL DISCLAIMER. This report was prepared as an account of work sponsored by an agency of the United states Government. Neither the Unlted states Government nor any agency thereof, not any of their employees, nor any of their contractors, subeontractors or their employes, mikes any warranty, express or implifed, or assumes any legal liability or responsibility for the accuracy, completeness, or any third party's use or the results of such use of any fiformation, apparatus, piroduct, or process disclosed, or represents that its use would not infring privately ouned rights. Reference hereln to any specific comercial product, process, or service by trade neme, trademark, manufacturer, or otherwise, does not necessarily' constitute or imply its endorsentent, recominidation, or fovoring by the United States Government or any agency thereof or its contractors or subeontractors. The viewe and opinions of authors expressed herein do not necesserily state or raflect those of the Unt ted states Government or any agency thereof. This report has been reproduced from the best avaflable copy. Printed in the United States of America. 
HNF -3584

REV. 0

FMEF ELECTRICAL SINGLE LINE DIAGRAM AND PANEL SCHEDULE

VERIFICATION PROCESS 


\begin{tabular}{|c|c||}
\hline FMEF ELECTRICAL BINGLE LINE DIAGRAM & HNF-3584 \\
REV. 0 \\
AND PANEL SCHEDULE VERIFICATION PROCESB & Pg 2 Of 10 \\
\hline
\end{tabular}

1.0 SCOPE

To provide a historical account of the field verification process performed on the FMEF Electrical single Line Diagrams and Panel Schedules.

\subsection{PURPOSE}

Since the FMEF did not have a mission, a formal drawing verification program was not developed, however, a verification process on essential electrical single line drawings and panel schedules was established to benefit the operations lock and tag program and to enhance the electrical safety culture of the facility. The purpose of this document is to provide a basis by which future landlords and cognizant personnel can understand the degree of verification performed on the electrical single lines and panel schedules. This document is written as a historical account of the verification process rather than a requirements procedure. It is the intent that this document be revised or replaced by a more formal requirements procedure if a mission is identified for the FMEF. It must be noted that the confidence levels established for these drawings may not be valid if configuration control is not maintained after facility shutdown.

\subsection{BACKGROUND}

The single line and panel schedule verification process has been a continuing process which began in 1990. It was an informal process since a rigid requirements document was not specifically developed for the effort, however, the ultimate goal of the process was the same, to obtain drawings that matched the field, and be used with a certain degree of confidence and to enhance the electrical safety of the facility. The results were used to develop new CAD drawings of the facility single lines and panel schedules. 
The load verifications were primarily performed by Operations using the Job Control system. Formal work packages such as 4M-90-104/W, 4M-91-207/M, 4M-92-219/W and 4M-97-192/W were written to perform various aspects of the verification process, but much of the work was also performed by use of J3's. The technical verifications were performed by the cognizant engineer and the facility electrician as panels and other electrical equipment were opened for inspection. They also supported the process by resolving discrepancies found by operations during the effort.

Information obtained from completed facility PMs in which equipment was tagged out through the lock and tag program or through tag outs from completed electrical work packages were also used as input to the verification process.

\subsection{VERIFICATION PROCESS}

There were two aspects associated with the verification process. First, the verification of equipment nameplate data and the installed hardware were compared to the drawing. Information such as bus size, voltage rating, number of phases, frequency, short circuit rating, breaker ratings, related components and pertinent information were verified. This part attempted to verify the technical aspects of the equipment.

In a few cases, the technical information was not available, lost or not consistent with design documents and the field. In these cases, an engineering evaluation had to be made with the available information and the manufacturer was often consulted. For example, several Federal Pacific Electric power distribution panels on the $70^{\prime}$ level did not have nameplates. The distributer was called who sent catalog cuts, design information and pictures of a panel that was manufactured during the time period that matched the exiting installation identifying it as a FPE, Type LDP panel. That aspect of the panel was considered verified. In another example, the volt-amp rating of the control transformer in a Westinghouse MCC starter had faded or was missing, however, the same type of transformer was used in several other Westinghouse MCCs of the same type, size and function and vendor information indicate that they are of 
the same specifications, therefore, the transformer was considered verified.

The second part of the process involved the verification of the loads supplied by the breaker. Since the FMEF did not have a mission, many of the process loads were not operational, some were not tested and others were inaccessible. For these reasons, load verification was performed in several different ways. Primarily, the supply breaker was used to energize and deenergize the load. If this was not possible, other methods such as using a trace signal to "ring out" wires, visually tracing wires from supply to load, using design drawings and other available technical information or a combination of these methods were utilized. As a result, confidence levels were developed to describe the degree of verification performed on the drawing. This part attempted to verify that the breaker listed supplies the load described.

For loads that could not be energized or deenergized, visually traced or "rang out", an evaluation was made using the best information obtained from the verification process and compared it with other supporting design documentation. For example, a duct heater is inaccessible but conduit containing the supply wires can be seen from the panel to the heater and there are no junctions in the conduit. The heater was considered verified. In another example, the duct heater is inaccessible and conduit containing the supply wires can be seen from the panel but part of the installation is embedded in concrete or concealed between walls, but other supporting design drawings show the installation and there is reason to believe that the drawing is correct. The heater was considered verified. However, if design documents do not provide sufficient information and an engineering evaluation must be made, the heater may still be considered verified but to a lessor confidence level as the previous example.

Operations personnel performed the load verifications by physically operating breakers in the field and checking off the loads on the drawing as they were tested. Discrepancies noted were forwarded to the cog engineer for resolution. The cognizant engineer and the facility electrician performed the technical verification by opening electrical equipment and checking the nameplate information to verify the equipment technical data and by "red lining" the latest 


\section{FMEF ELECTRICAL GINGLE LINE DIAGRAY}

drawings. Discrepancies noted by operations that required engineering or electrician assistance were also addressed using the verification methods described earlier. The cog engineer subsequently consolidated comments and issued direct changes to the drawings using the ECN process. Work packages were also generated to correct hardware discrepancies in cases where the drawing was found to be correct.

\subsection{VERIFICATION CONFIDENCE LEVELS}

Due to budget constraints and manpower availability, less emphasis was placed on verifying process loads that were deferred or not in use due to a lack of facility mission; and efforts were focussed on building loads that were most utilized, but the ultimate goal was to eventually verify all loads. The verification effort was a continuing process and confidence levels were developed based on the level of verification performed on each drawing or piece of equipment. The verification confidence levels are described briefly below as they apply to the single line and panel schedule drawings.

\subsection{ELECTRICAL SINGLE LINE DIAGRAMS}

Single line drawings are diagrammatic in nature. They show by means of single lines and graphic symbols, the course of the electrical system and the major component devices used therein. The technical specifications of the major components of the system such as size, ratings and capacities are typically shown. Less significant components, routing, connection information, controls and other details are normally not provided depending on the type of equipment described.

There were two aspects to the verification process for single line diagrams. First, the verification of the technical aspects of the equipment, and second, the verification of the loads that are being supplied by the breakers. Confidence levels were developed to describe the level of verification performed for these drawings as described below and will be listed as a 
PMEF ELECTRICAL GINGLE LINE DIAGRAM

HNF $\mathbf{- 3 5 8 4}$

REV. 0

AND PANEL BCHEDULE VERIFICATION PROCESS

Pg 6 of 10

note to each drawing that has been verified through this process.

\section{$99 \%$ CONFIDENCE LEVEL}

Verify by field verification the bus size, ratings, capacities, pertinent technical information and relations between pertinent components are accurately shown on the drawing.

Verify by field verification the loads supplied by the breakers are correctly shown on the drawing. Load verification was performed in several ways.

- Physically energizing and deenergizing the load

- Through previously known equipment tag out process which verified loads such as equipment PMs and corrective maintenance work packages

- By visually verifying wires from supply to load

- By visually verifying conduit containing supply wires from the supply to the load and the conduit does not contain any junctions between the panel and the load

- By visually verifying wires from the supply that enter conduit that may be concealed or embedded, however, the same wires are seen leaving the conduit at the load end, or supporting design drawings show the routing of the wires and conduit and there is reason to believe that the drawings are correct (This method primarily used in verifying non-operational loads on MCC single Lines only)

\section{$90 \%$ CONFIDENCE LEVEL}

Same as $99 \%$ CONFIDENCE LEVEL except that less than $10 \%$ of the loads may have been verified using an engineering evaluation. Supporting design drawings were consulted but may not have shown the entire installation and other documents were used to complete the evaluation. It is reasonably certain that the evaluation is correct. The technical aspects of the equipment have been verified. 


\section{FMEF ELECTRICAI BINGLE LINE DIAGRAY}

$\mathrm{HNF}-3584$

REV. 0

AND PANEL BCHEDULE VERIFICATION PROCESB

Pg 7 of 10

\section{0\% CONFIDENCE LEVEL}

Same as $99 \%$ CONFIDENCE LEVEL except that there are loads that have not been field verified using any of the listed methods above. The technical aspects of the equipment have been verified.

\subsection{ELECTRICAL PANEL SCHEDULES}

Panel schedules are typically shown in table form, listing the loads connected to each respective circuit breaker of the distribution panel being described. It also provides the technical specifications of the panel such as the bus size, ratings, capacities and circuit breaker configuration (single pole, double pole, etc.).

There were two aspects to the verification process for panel schedules. First, the verification of the technical aspects of the equipment, and second, the verification of the loads that are being supplied by the breakers. Confidence levels were developed to describe the level of verification performed for these panels as described below and will be listed as a note to each drawing that has been verified through this process.

\section{9\% CONFIDENCE LEVEL}

Verify by field verification the bus size, ratings, capacities, breaker configuration and pertinent technical information are accurately shown on the drawing.

Verify by field verification the loads supplied by each circuit of the panel are correctly shown on the drawing. Load verification was performed in several ways.

- Physically energizing and deenergizing the load

- Through previously known equipment tag out process which verified loads such as equipment PMs and corrective maintenance work packages

- By using a trace signal to "ring out" the circuit

- By visually verifying wires from supply to load 
- By visually verifying conduit containing supply wires from the supply to the load and the conduit does not contain any junctions between the panel and the load

- By visually verifying wires from the supply that enter conduit that may be concealed or embedded, however, the same wires are seen leaving the conduit at the load end, or supporting design drawings show the routing of the wires and conduit and there is reason to believe that the drawings are correct

\section{$90 \%$ CONFIDENCE LEVEL}

Same as $99 \%$ CONFIDENCE LEVEL except that less than $10 \%$ of the loads may have been verified using an engineering evaluation. Supporting design drawings were consulted but may not have shown the entire installation and other documents were used to complete the evaluation. It is reasonably certain that the evaluation is correct. The technical aspects of the equipment have been verified.

\section{0\% CONFIDENCE LEVEL}

Same as $99 \%$ CONFIDENCE LEVEL except that less than $20 \%$ of the loads may have been verified using an engineering evaluation. Supporting design drawings were consulted but may not have shown the entire installation and other documents were used to complete the evaluation. It is reasonably certain that the evaluation is correct. The technical aspects of the equipment have been verified.

\section{0\% CONFIDENCE LEVEL}

Same as $99 \%$ CONFIDENCE LEVEL except that there are loads that have not been field verified using any of the listed methods above. The technical aspects of the equipment have been verified. 


\subsection{SUMMARY OF VERIFICATION RESULTS TO DATE}

It was learned that the verification process had taken a much broader scope of work than originally thought. It was not simply revising the drawing to match the field; but there were conditions where the field was correct and drawings wrong. These discrepancies were resolved by direct change ECNs to the drawings. In many cases the verification process provided information which added or clarified existing information. However, there were conditions where the drawings were correct and the field was wrong. Work packages were generated to correct these deficiencies. There were conditions where both drawing and field conditions were wrong and vendor information had to be consulted; and still other conditions where vendor information, design drawings and installed equipment were all showing incorrect or partially correct information and an engineering evaluation had to be done with frequent consultations with the manufacturer. Work packages and ECNs were then generated to correct these deficiencies as required.

To date, there has been a level of verification performed on all major electrical sWGRs and MCCs shown on the latest single lines (H-4-112462 through $\mathrm{H}-4-112489$ ) with the exception of MCC B20 and MCC B22 located in Room 605C. The two MCCs were installed by the SAF project to supply the automated fuel fabrication line which has no mission and the equipment never used.

There are approximately 127 panelboards associated with the FMEF. There has been a level of verification performed on all panelboards (shown on $\mathrm{H}-4-112460$ and $\mathrm{H}-4-112461$ ) with the exception of PP-100 located in Room E125. Many of the panels contained circuit breakers that supplied loads that were deferred, inaccessible or not used due to lack of mission. Because of funding constraints and the availability of manpower, verification of these loads was not emphasized and more focus was placed on panels being utilized in the facility. It must be noted that there are many "cord and plug" connected loads such as HLAN equipment, computer equipment, vending machines, electric ranges, refrigerators, etc. that may eventually be removed from the facility during shutdown and may not be reflected on the panel schedules. Work packages such as $4 \mathrm{M}-92-219 / \mathrm{W}$ and $4 \mathrm{M}-$ 


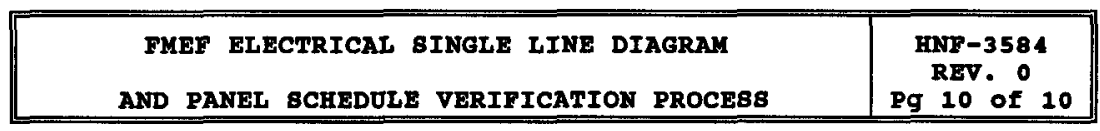

97-192/W may remain open since the verification process is continuing.

\subsection{CONCLUSION}

It is believed that the verification process has improved the quality of the electrical single lines and panel schedules tremendously, and although the drawings may not be entirely perfect at this time, it provides reason to continue the verification process. It is the intent that this document be revised as other drawings are added to the verification process, or be replaced by a more formal requirements procedure if a mission is identified for the FMEF in the near future. 